\title{
A crise dos vínculos de confiança nas interaçôes da prática médica: uma nova configuração no contexto histórico contemporâneo
}

SCHRAIBER, Lilia Blima.

O médico e suas interaçôes: a crise dos vínculos de confiança.

São Paulo: Aderaldo \& Rothschild, 2008. 254p. (Saúde em Debate; 186).

Apresentação: Ricardo C. M. Ayres

| Vanessa Maia Rangel |

Doutoranda no Departamento de Política, Planejamento e Administração em Saúde do IMS-UERJ; bolsista CNPq. Endereço eletrônico: tufaha@terra.com.br.

O principal mérito do livro de Lilia Schraiber parece se encontrar nas palavras de José Ricardo Ayres, seu apresentador, de mostrar um "médico profundamente real e humano, sujeito de interação nos e por meio das técnicas que desenvolve e manuseia e que está em estreito contato com importantes escolhas da Vida Boa e aos justos meios de chegar a ela, intimamente ligados ao cuidado da saúde em seus contextos concretos de prática” (p. 15). Seu objetivo é evidenciar, através da compreensão dos paradoxos morais dos saberes e práticas do médico, a possibilidade de um entendimento das práticas de saúde contemporânea, abordando especificamente a crise de confiança nas relações interpessoais do médico em seu trabalho.

Como marco para a compreensão dessa crise, a autora aponta a passagem da medicina liberal para a medicina tecnológica, e se posiciona no epicentro de algumas das principais tensōes do trabalho do médico e da produção da assistência, sendo o que reforça sua ideia de que, estudando o processo de trabalho médico, poderia compreender como este agente se insere nesse processo e como se vê como profissional.

Essas tensóes, segundo a pesquisadora, se referem à ampliação do assalariamento e da perda de autonomia mercantil do médico, da intensificação dos conflitos de base institucional acerca do controle da clientela e das condições de trabalho, da maior complexidade da técnica, da maior especialização, do aumento dos recursos instrumentais de intervenção, o que, em conjunto, suscitou novos dilemas relativos ao consultório-empresa e ao trabalho associativo. Para Schraiber, como 
consequência, verifica-se uma mudança significativa nas relações interindividuais e do sentido interativo de seus participantes, fazendo emergir a crise de confiança situada emblematicamente na medicina tecnológica.

O livro analisa o desenrolar deste processo em cinco capítulos, partindo do primeiro, onde é feita uma análise do trabalho médico dentro da perspectiva da sociologia das profissões, enfatizando a autonomia como valor central desta profissão e que sofre mudanças de acordo com o avanço tecnológico. A autora examina a medicina como prática técnica e social e conceitua o médico como "agente de sua ciência e sua prática e participante, portanto, da criação da sua experiência clínica que rege a sua ação concreta. Esta ação é guiada e delimitada pelo contexto social, onde cumprir suas finalidades sociais respondendo às necessidades que são postas acaba sendo a sua própria necessidade: exigências colocadas para a prática dos médicos e percebidas como necessidades médicas, ou seja, dos próprios médicos" (p. 37). Desta maneira, a apreensão dos objetivos sociais da prática médica compreende capturar o sofrimento de indivíduos como doença, localizar a doença no corpo, agir sobre as alteraçôes patológicas e restituir o doente à vida social cotidiana, produzindo cuidados sob ritmos e formas compatíveis com a imagem e o significado moderno do corpo, qual seja, um corpo trabalhador. A autora prioriza o que se chama "saber operante" para entender a produção desse corpo trabalhador, saber portador de intencionalidades técnica e social. Configura-se, portanto, que a hipótese de compreensão da crise dos vínculos de confiança na esfera do trabalho médico perpassa a transformação da autonomia profissional do médico em autonomia técnico-tecnológica, que, segundo a autora, seria "uma transformação para a manutenção" (p. 41) do exercício autônomo ao mesmo tempo em que se constrói outra maneira de se praticar a medicina.

No capítulo dois, a autora apresenta sua estratégia metodológica de pesquisa que se baseou em entrevistas abertas com médicos de diferentes idades, sexos e especialidades, todos tendo inserção de trabalho predominante na região da grande São Paulo. A seleção dos sujeitos se deu por recomendação dos primeiros entrevistados para facilitar a recepção e a interação da pesquisadora com os sujeitos. O enfoque das entrevistas foi localizado nas histórias de vida do trabalho dos médicos, sendo a análise através da técnica da saturação, valorizando as representaçôes desses médicos acerca de suas práticas, identificando os agentes técnicos e os sujeitos históricos. 
Seguindo o capítulo três sobre a medicina ontem e hoje, a pesquisadora disponibiliza os relatos das entrevistas, que embora muito diferentes entre si, convergem na problematização da transformação histórica gradual do trabalho médico, que se reflete muito apropriadamente nos discursos das diferentes faixas etárias dos médicos entrevistados. Considerando este recorte, para os médicos mais velhos, que atendiam em casa, o trabalho era lidar com o material humano nobre; para os mais jovens, em sua maioria especialista, tratava-se da responsabilidade profissional de se fazer uma medicina tecnológico-hospitalar, da demanda crescente do número de atendimentos em um tempo cada vez menor, configurando uma tensão entre lidar com esse apontado material humano versus a produtividade. Essa complexificação da medicina encenada especificamente na era dos seguros de saúde representa, para os médicos mais jovens, a crise da confiança, pois a escolha do profissional de cuidado passa a se dar principalmente por arranjos econômicos e não sociais-afetivos, fazendo, portanto, a relação médico-paciente uma relação de caráter econômico. Esta relação é complicada, por sua vez, pelo autoprotecionismo em relação aos processos judiciais, tornando estas relações mais distantes e amedrontadas.

Na visão da autora, este processo de mudança traz conflitos para a percepção do que é ser médico, pois insere na identidade de médico múltiplas facetas possíveis e correspondentes à multiplicidade das situações de trabalho que exigem ao mesmo tempo autossuficiência e parceria. Assim, se "na medicina liberal podiase reconhecer o binômio homem-de-vocação-homem-esforçado, a medicina tecnológica demanda um outro binômio em que se articulam a competência e a sagacidade de se autoempreender" (p. 170). Além disso, diante da maior gama de conhecimentos disponíveis, dos meios de comunicação de massa, da medicina defensiva e ainda das incertezas e dos riscos implícitos em todo julgamento e decisões médicas, o desafio é estabelecer uma relação interativa muito diferente do que tem caracterizado a prática médica, conquistando-se uma abertura para o diálogo e compartilhando juízos e decisões.

Isto implica, para Schraiber, ato muito mais difícil, devido a um trabalho reflexivo muito mais complexo: "há que se reconquistar a possibilidade de se produzir o cuidado efetivo, julgar o caso com adequado discernimento, decidir com alguma certeza e precisão e atuar com a cumplicidade parceira do paciente" (p. 208). No entanto, a meu ver, isto não configura o elemento de reconquista para a profissão 
médica, pois trata-se do próprio ideal da profissão, ou seja, agir sensivelmente de modo a não ser negligente, imprudente ou imperito diante das condições contextuais da prática. A mudança que se observa nos relatos das entrevistas de Schraiber são transformações históricas na dinâmica do trabalho, que passa a incluir novos agentes/parceiros, novos instrumentos e novas instituições, tensionando os valores mais caros da prática médica sem anulá-los, muito pelo contrário, dando visibilidade a estes valores que parecem ser reposicionados nos diferentes novos elementos desta dinâmica que se complexifica.

Este entendimento parece estar contemplado no quinto capítulo, onde a autora sintetiza os achados relativos ao momento histórico de mudança da medicina liberal para a tecnológica, delimitando, portanto, uma diferente sensibilidade e as possibilidades adaptativas promovidas pela tensão entre valores éticos profissionais e mudanças estruturais na prática médica. 